\title{
The benefits of salon dance for elderly: systematic review
}

\begin{abstract}
This research aimed to analyze the relationship between ballroom dancing and the benefits for the elderly. The research followed the modality of systematic review, this researcher model was chosen because it is a type of research that allows the study of published researches that show relevant contents so that they can be condensed, in which generate general conclusions about the subject addressed In the study, the hope of perfecting theoretical knowledge. According to the results found, the hall dance for the elderly expanded every day, because it is a physical activity that works not only the body, but also the mind. The most discussed benefits in the studies found are related to emotional well-being, gain of agility and balance, benefit of cognitive attention and promotion/recovery of health.
\end{abstract}

Keywords: benefits, ballroom dance, elderly
Volume 3 Issue 5 - 2018

\section{Maurício CS Cunha Lima, Maria do Livramento Silva Bitencourt Edienne Rosângela Sarmento Diniz, Cecília NGA Valença \\ Master of Nursing, Lauro Wanderley University Hospital, Brazil}

Correspondence: Maria do Livramento Silva Bitencourt, Master of Nursing, Lauro Wanderley University Hospital, Brazil, Email luiznascimento_@outlook.com.br

Received: September 19, 2018 | Published: September 27, 2018

\section{Introduction}

According to the guidelines of the World Health Organization (WHO) (2000), ${ }^{1}$ the elderly population is determined from 60 years of age, with life expectancy up to 74 years old by 2025 . Therefore, for Silva and $\mathrm{Mazo}^{2}$ the demographic growth of the elderly population is of great interest on the part of scholars. Studies have focused on the older population and, for the most part, the regular practice of physical activity is inserted as a priority in health and improvement of the quality of life of this population.

It is known that aging can cause several physiological and functional changes, such as: paralysis, chronic diseases, pain, imbalance and gait. Studies highlight these changes as an impact factor in social life, since the maintenance of a physically active lifestyle can ease the symptoms, promoting and reducing the risks of sedentarism. ${ }^{3}$

To that end, Faranatti ${ }^{4}$ the benefits of regular physical activity practice have positive implications on the quality and life expectancy of the elderly. In general, in the old age, regular physical exercises facilitate psychomotor speed, coordination, neuropsychological performance and postural control, in addition to providing socialization between peers and the general well-being of the organism.

Among the programs that can help in the fight against the sedentary lifestyle in this population are the exercises to strengthen the muscles, they are: aerobics (walking, swimming, pedaling, water aerobics, dancing) and also activities of daily life and leisure, such as taking care of household chores, tending the garden and climbing stairs, all with mild to moderate intensities and always targeting the personal preferences and possibilities of the elderly. ${ }^{5}$

The quality of life has many senses, including the search for satisfaction in the family, love, social, environmental and in the existential esthetics itself, presupposing to be a social determinant of the standards of comfort and well-being. ${ }^{6}$

With regard to dance for the elderly, it has a strong socializing and motivating character. It is denoted as being a lifelong practice that arouses new feelings and some capabilities that the old man never imagined he could have. When practiced regularly, it can prevent degenerative diseases. ${ }^{7}$

Dance can still offer real possibilities for experiencing and amplifying the emotions and perceptions provided by this exercise. It can also bring benefits to its practitioners as physical health improvement, (respiratory, digestive, reproductive and excretory systems), as well as in the organo-functional conditions (circulatory, respiratory, digestive, reproductive and excretory). Dance can also be decisive in improving self-esteem, providing independence and interaction with other people. In addition, it provides the perception of possible limitations, that is, the experience of success situations and failures that are typical of daily life. ${ }^{8}$

Besides being a well-accepted physical activity by the elderly, dance allows the acquisition of new abilities and improves the motor capacity, allowing the accomplishment of more complex movements, in particular concerning the coordination of both the upper and lower limbs. ${ }^{9}$

The practice of regular and systematic physical activity, in dance mode, in the elderly, increases or maintains physical fitness, thus improving their well-being. Added to this is the reduction of the morbidity and mortality rate, as well as the prevention or retardation of many diseases, leading to an increase in their life expectancy. ${ }^{10}$

It is possible to delay the normal decline associated with aging with dance practice. For, dance can be practiced by both an athlete and an elderly person. It all depends on the interest, motivation, the pleasure to dance and the relationship that one has with his body. ${ }^{9}$

Dance is a physical activity of body and soul. It is perceived that the human being composes an intelligent body, a body that dreams, reacts, is moved, suffers and has affections. Each subject with his or her body history. The Hall dance for the elderly person causes the motor coordination to present itself in an improved way along with its reflexes, thus improving its quality of life and avoiding even falls. ${ }^{8}$ 
This study proposal is justified by the need to carry out a new research under the proposed theme, since it is known that ballroom dancing is practiced as a form of entertainment, social integration and as a sport. Female weight is necessary for psychological and body health, and is ideal for all ages. Note with the arrival of the third age the body and the mind passed by changes, and together with them they reach the limitations. It is not easy to go through and adapt to this new cycle of life. ${ }^{11}$

Still for the author mentioned above, at this stage of life, the elderly people who previously worked had a work routine with activities during the day, if they see at home with nothing to do, this can cause illnesses such as depression. It is no news that dance brings many benefits to all, but the elderly can benefit these benefits, and the modality perfectly fits the needs and conditions of that age. It is necessary to improve the quality of life, and nothing better than physical activities that work beyond the body the soul

It is also justified because the dance considered as physical activity helps in the strengthening of the muscles, in the breathing, and also in the balance, that in the lack of the same in this age group is the cause of many accidents. She works the social issue, since most of it is practiced in a group. It is essential that the elderly person has a routine, feels useful, alive and independent. And this is what dance tries to develop.

It requires a better understanding and understanding that even if it does not seem at times, old age is considered a risk group. It is very important that the teachers who coordinate this type of class are aware of this fact. Each group has its limitations, and with them it is no different. If more people discover the benefits that dance can bring, we will have more willing, quiet and more willing to live.

In this way, the objective was to analyze the relationship between ballroom dancing and the benefits for the elderly, especially checking in the scientific articles the benefits of ballroom dancing for the elderly and investigate what science has been building on the proposed theme.

\section{Method}

The research follows the method of systematic review, this research model was chosen because it is a type of research that allows the study of published research that shows relevant contents so that these can be condensed, in which generate general conclusions about the subject addressed in the study, the hope of perfecting theoretical knowledge. ${ }^{12}$

A systematic review, as well as other types of review studies, is a form of research that uses as a source of data to the literature on a certain theme. This type of information can be applied through methods of explicit and systematized search, through the analysis of information. Systematic reviews are particularly useful for integrating information from a set of studies conducted separately on a particular therapy / intervention, which may present conflicting and / or overlapping results, as well as identify issues that require evidence, assisting in guiding future research. ${ }^{12}$

Initially, the question was asked to guide the study, where the five stages will be followed: establishment of inclusion criteria and exclusion of studies and search in the literature, categorization of studies found, evaluation of included studies, interpretation of the same, and finally, presentation of the systematic review.
Our problem is the characterization of the benefits of the dance of the hall for the elderly, in a social and affective perspective of this same public. Identifying the modifications in the motor learning of participants of the dance classes.

For inclusion criteria: searches in the database Index Psicologia, LILACS e CAPES existing Biblioteca Virtual de Saúde (BVS), in the period between 2006 to 2016, with the use of the following descriptors in Ciências da Saúde (DECS): "Benefits", "Ballroom dance" "Seniors", in Portuguese and English, complete text. The articles that do not contemplate the objectives of this research, articles repeated in the databases and that are not in full.

The main intention with this research was to expose that through the regular practice of ballroom dancing the elderly will have a better quality of life providing a physical and mental wellbeing, in addition to interaction with other elderly people. Ballroom dancing also aims at citizenship, as it is a pleasurable physical activity for different audiences and also opens up opportunities for the development of motor coordination, flexibility and respect for others. ${ }^{13}$

With the practice of dance with the elderly is intended to analyze the evolution of performance in their daily activities and their perspective of life. With the help of a Physical Education teacher, more precisely the dance teacher, will provide greater safety and enhancement of dance techniques by also stimulating brain exercise activities.

The relation between Physical Education and Dance of the Salon is justified as two contents that are totally linked to the prevention and improvement of physical or psychological illnesses. As such, they will always be walking together contributing to human health and evolution. ${ }^{13}$

The aim of this study was to analyze the relationship between ballroom dancing and benefits for the elderly, to verify in the scientific articles the benefits of dance in a social and affective perspective in the elderly, and to carry out an investigation about what science has been building about this subject.

Finally, our analysis of data was given by Bardin, who defines content analysis as a set of communication analysis techniques, which uses systematic procedures and objectives to describe the content of the messages. The intention of the content analysis is the inference of knowledge regarding the conditions of production. Therefore, in view of the foregoing, it is perceived that the content analysis is a set of communication analysis techniques, which aims to overcome the uncertainties and enrich the reading of the collected data. ${ }^{14}$

\section{Results}

A total of 107 articles were found according to this systematic review, of these, after inclusion and exclusion criteria 10 (ten) articles composed the total sample. The Table 1 will demonstrate empirical research data according to author, year of publication, periodical, completion, and database.

Gil et al. ${ }^{15}$ gives Revista Kairos, understands that dance can be a physical activity that, practiced throughout life, can contribute to an active aging. (AU). Already Benetti et al. ${ }^{16}$ gives ABCS Helth Sc, emphasizes that the use of the Senior Dance as a resource in occupational therapy for healthy elderly people provides autonomy, self-knowledge and resignification of daily life. 
Table I The table shows the I0 studies featuring three publications in the year $20 \mathrm{I} 5$, two in the year $20 \mathrm{I} 4$, one in the year $20 \mathrm{I} 2$, one in the year $20 \mathrm{II}$, one in 2010 and two in 2008

\begin{tabular}{ll}
\hline Author Name & Title \\
\hline Gil $^{15}$ & Leisure and physical activity habits during the course of life in elderly people practicing dance \\
Benetti $^{5}$ & A proposal of public policy of physical activity for the elderly \\
Silva Berbel et al. ${ }^{25}$ & The benefit of senior dance in relation to balance and daily life activities in the elderly \\
Andrade et al. ${ }^{1}$ & Perception of the elderly in a cohabitation group: a study in the city of Cajazeiras-PB \\
Barboza et al. $^{2}$ & Effectiveness of dance-associated physiotherapy in healthy elderly subjects: randomized clinical trial \\
Ueno et al. $^{32}$ & Effects of three modalities of physical activity on the functional capacity of the elderly \\
Silva et al. & Influence of dance on the muscular strength of the lower limbs of the elderly \\
Paiva et al. ${ }^{25}$ & Dance and Aging: A Partnership on the Move \\
D'alencar et al. & Biodance as a process of existential renewal of the elderly \\
Catib, et al. ${ }^{6}$ & Emotional states of the elderly in circular dances \\
\hline
\end{tabular}

Source Data of the author, 2017

In this sense, Silva e Berbel ${ }^{17}$ gives ABCS Helth $\mathrm{Sc}$, in their study, suggest that senior dance is beneficial in relation to balance and daily life activities in the elderly.

Therefore, Andrade et al. ${ }^{18}$ gives Revista Brasileira de Geriatria e Gerontologia the groups provide gains for the elderly, signaling among them the right to age with dignity and improving the quality of life.

Still, Barboza et al. ${ }^{19}$ gives Revista Brasileira de Geriatria e Gerontologia shows that the proposed program proved to be effective for improving balance, flexibility and agility in the individuals submitted to the intervention.

For Ueno et al. ${ }^{20}$ gives Revista Brasileira Educação Física, it is concluded that the practice of regular and systematized physical activity, regardless of the modality, can have a positive influence on the functional performance of the elderly, being able to preserve their independence and autonomy.

In the period Revista Kairós, Silva et al. ${ }^{21}$ brings that the discourse of the participants demonstrated, however, that there was perceptive improvement of the elderly regarding muscular strength and also mobility, joviality and self-esteem. It is suggested that the effect of the dance, practiced in the frequency used in this study, causes greater effect on the well-being and the psychosocial sphere of the individual than on the measurable muscular force.

Already Paiva et al.22 gives Revista Brasileira Atividade Física Saúde, says that there are numerous published results, corroborating with the scientific literature on the benefits of regular dance practice. D'alencar $^{23}$ da Revista Brasileira Enfermagem It says that in this sense, dance promotes the rescue of the health of people who grow old.

Although, Catib et al. ${ }^{24}$ da Motriz Revista Educação Física, Considering the positive results pointed out, other reflections on the resonances of this practice become more pressing, improving aspects related to functional well-being and other primary well-being in the life of the elderly.

\section{Discussion}

\section{Dance and music linked to benefits for the elderly}

Gil et al..$^{25}$ brings that at present many studies have turned to the third age, showing that one of the modalities most sought by the elderly to exercise regularly is the dance. Some authors claim that, practicing the regular way, dancing is not as different as physical ones, as they are psychological and social, thus preventing various degenerative diseases. For that, it was observed that of the 10 articles surveyed, 06 articles relate dance to psychological benefits.

In this sense, Benetti ${ }^{16}$ states that music is a valuable element in the context of physical activity for the elderly population. Music can bring them to various sensations produced by prolonged and repetitive exercise, helping to keep the life more active and with better quality. Already, among analyzed articles, articles de Andrade ${ }^{18}$ Barbosa $^{19}$ $\mathrm{Ueno}^{20}$ the importance of music for this age group.

In the study of Andrade et al. ${ }^{18}$ it can be seen that dance can offer several real possibilities for experiencing and amplifying the emotions and perceptions provided by this exercise. Among the articles, Andrade et al. ${ }^{18}$ Ueno et al. ${ }^{20}$ e Barbosa et al. ${ }^{19}$ understand that dance can also be decisive in improving self-esteem, providing independence and interaction with other people. In addition, it provides the perception of possible limitations, that is, the experience of situations of success and failures typical of everyday life. Following the same line of thought, we find in the article Benett ${ }^{16}$ similar results, highlighting the improvement of the motor capacity of the elderly.

We found in the Andrade et al. ${ }^{18}$ the perception of dance as a possibility to bring benefits to its wheelchair practitioners as an improvement in physical health. Still following the same line of reasoning as Andrade et al. ${ }^{18}$ Silva et al. ${ }^{21}$ emphasize that the practice of regular and systematic physical activity, be it dance or any other modality, in the elderly deficient or with difficulties of locomotion, increases or maintains physical fitness, thus improving their wellbeing. 
For Ueno et al. ${ }^{20}$ besides being a physical activity very well accepted by the elderly population, in turn the dance allows the acquisition of new abilities and improves the motor capacity, allowing the realization of more complex movements, in particular referring to the coordination of the upper and lower limbs. In this same thought, we find in article Benetti ${ }^{16}$ similar results, highlighting the improvement of the motor capacity of the elderly.

According Witter et al. ${ }^{26}$ dance is an expressive form of movements guided by music. Dancing arouses positive emotions, pleasure and socialization. It is these factors that motivate the individual to dance and keep them engaged in the activity. Only in the last years did systematic studies on body image and dance appear, highlighting its performance in the biopsychosocial process, within the scope of health promotion, of an active and healthy aging. Already for Paiva et al. ${ }^{22}$,Uneno et al. ${ }^{20}$ agree that aging produces a progressive loss of functional abilities of the organism, and these changes end up limiting the ability of the elderly to perform their usual activities.

Still for the same authors, the image that is configured from this is of incapacity, adopting the position of dependence, giving rise to feelings of uselessness and solitude that leads to the gradual loss of affective and social relations. Thus, the aging of the population translates into a greater burden of diseases and disabilities, reflecting the greater demand of the elderly for health services.

In contrast D'alencar et al..$^{23}$ affirms that it is necessary, therefore, to improve the qualification of professionals belonging to the multiprofessional team, who work directly or indirectly with this public, in order to try to minimize the impacts inherent to this period of life, providing a successful aging with quality of life.

In his study, Catib et al. ${ }^{25}$ well-being in old age, or health in a broad sense, would be the result of the balance between the various dimensions of the functional capacity of the elderly, without necessarily meaning absence of problems in all dimensions. In this sense, the advantages of practicing physical exercises for the elderly depend on how aging is practiced and the routine practiced.

A good exercise program for the elderly should emphasize flexibility, aerobic endurance and strength for maintaining muscle mass, obviously depending on the professional attention brought per D'alencar et al. ${ }^{23}$ Interventions should be adapted to the individual's desires, according to their preferences and needs, in order to assist in the maintenance of physical activity in the adult, sedentary and active elderly. In this context, dance contributes significantly to the improvement and / or maintenance of several dimensions that are included in the term "quality of life", among them social integration, adaptation to preexisting conditions and functional aptitude. Therefore, Paiva ${ }^{22}$ affirms that dance is an expressive form of movements guided by music. Dancing arouses positive emotions, pleasure and biopsychosocial social, within the scope of health promotion, of an active and healthy aging.

\section{Aging and dancing}

It was observed in our research, through our analyzes, that the human feeling of aging and dance are conditioned in the same sense when together practiced, according to the comparison of the studies below related we can observe the coherent inquiries according to the scholars.

Gil et al. ${ }^{25}$ affirms that the quality of life of the elderly, fundamentally, only makes sense if we think of these beings from the basic requirements to live in society from reflections on food, housing, clothing, education, health and leisure. Therefore, Ueno et al. ${ }^{20}$ e Silva e Berbel. ${ }^{17}$ that the limitations that affect human beings in advanced ages and the possible chronic diseases, should not be seen as obstacles to take advantage of what life offers to all, including this group of people. Thus, discussions such as these are pertinent to reflect on aging.

In the study of Silva et al. ${ }^{17}$ we find the activity of dance related to the rescue of culture, which in turn creates spaces to promote the learning of other cultures, feeling the value of the emotions that emerge from the movements, rhythms and forms of expression are individual, doubles, trios, quartets or great groups. In this same perspective, Paiva et al. ${ }^{22}$ highlights the importance of this theme, through socio-educational measures and programs directed to this age group. In our country, there are already institutions that are concerned with the elderly, who are trying to help them grow old with quality of life. Therefore, Silva et al. ${ }^{17}$ e Paiva et al. ${ }^{22}$ bring out the importance of dance related to cultural aspects, thinking from the aging process.

Andrade et al. ${ }^{18}$ affirms that there are many existing programs, however the non-adequacy of the proposed activities can be very harmful and not meet the needs of this population. In contrast, Catib et al. ${ }^{24}$ states that studies in the area of physical activity for the elderly have been carried out demonstrating the importance of this practice for the improvement of the quality of life of the elderly. Although these results are contrary to each other, they encourage us to rethink the appropriateness of the activities and the aging process in the elderly, which in our opinion can be thought of in the context of dance.

\section{Dance as culture and socialization}

We also find in our analysis the great article of Barboza et al. ${ }^{19}$ which in turn defines dance as one of the oldest artistic manifestations in the history of mankind whose language is about the body. Already for Paiva et al..$^{22}$ it is through dance that we express emotions, sensations that have emerged from the feelings that emerge from the moving body.

Still for the authors, the dance allows the human being to experience moments of joy, freedom, euphoria, as it makes it possible to transcend some limit of the body. In this case, the two studies converge for dance in a perspective of human manifestation. We noticed through our research, que Barboza et al. ${ }^{19}$ as well as to Paiva et al. ${ }^{22}$ have the same line of reasoning, where the bodies that dance, independent of gender, social class, age groups and disabilities, interact and socialize all the time.

Analyzing the articles, we observe that every human being can dance, be it man or woman, child, young or old, deficient or notThis set of movements and rhythms is a channel to know yourself, others, the environment, the environment and even the planet as a whole.

For D'alencar.$^{23}$ all the people who use the various forms of dance are by work, aesthetics, therapy or leisure, they even consider it as a means of leisure, since it is proper for the human being to feel the need to express himself using the body to do it, taking men and women, moved by passions and desires, to free themselves from the impositions that are daily inserted in their social life.

The author's statement shows how dance has been experienced and used to break prejudices, increase the chances of living and learn new body experiences. 
Finally, from a self-analysis, it is up to us to reflect at this moment, as we Physical Education professionals, we can act together with the elderly, exploring this content, with the purpose of encouraging these people to become capable of experiencing and encouraging other elderly people to do the same, dancing, and constantly socializing. ${ }^{27-34}$

\section{Conclusion}

This work allowed the identification of the importance and benefits of ballroom dancing for the elderly. It is known that the world population has an increasing percentage of elderly people, so methods are emerging so that this population lives in a healthier way.

We observed in our analysis that dance consists of a highly explored physical education field, especially when associated with aging.. For this, we realize that dance works the socialization, along with the physical and psychological benefits. In addition, dance, based on the articles analyzed, is associated with well-being, especially for the elderly.

This study also understood that even with physical pain, or other limitations related to the elderly, do not prevent them from participating in classes offered by institutions, because in their perspectives, they enjoy doing them. It was also observed a great advance of the elderly within the practice of ballroom dancing and the level of learning. All the evolution is due to the persistence in continuing to participate the dance classes according to the studies addressed in this research.

\section{Acknowledgements}

None.

\section{Conflict of interest}

Author declares that there is no conflict of interest.

\section{References}

1. Organização mundial da saúde (OMS). The World Report. Geneva: WHO; 2000 .

2. Silva AH, Mazo GZ. Dança para idosos: uma alternativa para o exercício físico. Cinergis. 2007;8(1):25-32.

3. Benedetti TRB, Gonçalves LHT, Mota JAPS. Uma proposta de política pública de atividade física para idosos. Texto e Contexto Enfermagem. 2007;16(3):387-98.

4. Farinatti PTV. Envelhecimento: promoção de saúde e exercício: bases teóricas e metodológicas. Barueri: Manole, 2008.

5. Nóbrega AC. Posicionamento oficial da Sociedade Brasileira de Medicina do Esporte e da Sociedade Brasileira de Geriatria e Gerontologia: atividade física e saúde no idoso. Rev Bras Med Esporte. 1999;5(6).

6. Minayo MCS, Hartz ZMA, Buss PM. Qualidade de vida e saúde: um debate necessário. Ciência \& Saúde Coletiva. 2000;5(1).

7. Leal IJ, Haas ANO. Significado da dança na terceira idade. Revista Brasileira de Ciências do Envelhecimento Humano. 2006.

8. Giraldi A, Souza MAC. Dança para cadeirantes: um exemplo de superação. Revista da Unifebe. 2011.

9. Sebastião E. Efeitos da prática regular de dança na capacidade funcional de mulheres acima de 50 anos. R da Educação. 2008;19: 205-14.

10. Cress ME. Relationship between physical performance and self-perceived physical function. J Am Geriatric Soc. 1995;43(2):93-101.
11. Veras R. Envelhecimento populacional contemporâneo: demandas, desafios e inovações. Rev Saúde Pública. 2009;43(3):548-54.

12. Linde $\mathrm{K}$, Willich $\mathrm{SN}$. How objective are systematic reviews? Differences between reviews on complementary medicine. $J R$ Soc Med. 2003;96(1):17-22.

13. Hass AN, Leal IJO. Significado da dança na terceira idade. Revista Brasileira de Ciência do Envelhecimento Humano. Passo fundo. 2006;1:64-71.

14. Bardin L. Análise de conteúdo Lisboa: Edições 70. (Obra original publicada em 1977); 2006.

15. НTTP://www.ibge.gov.br/home/

16. Benetti FA. A dança sênior como recursos terapêuticos para idosos. $A B C S$ Health Sci. 2015;40(1):4-5.

17. Silva JR. Influência da dança na força muscular de membros inferiores de idosos. Revista Kairós Gerontologia. 2011;14(1);163-179.

18. Andrade AN. Percepção de idosos sobre grupo de convivência: estudo na cidade de Cajazeiras-PB. Rev Bras Geriatr Gerontol. 2014;17(1):39-48.

19. Barboza NM. Efetividade da fisioterapia associada à dança em idosos saudáveis: ensaio clínico aleatório. Rev Bras Geriatr Gerontol. 2014;17(1):87-98.

20. Ueno DT. Efeitos de três modalidades de atividade física na capacidade funcional de idosos. Rev bras educ fis. 2012;26(2).

21. Silva JR. Influência da dança na força muscular de membros inferiores de idosos. Revista Kairós Gerontologia. 2011;14(1);163-179.

22. Paiva ACS. Dança e envelhecimento: uma parceria em movimento. Revista Brasileira de Atividade Física \& Saúde. 2010;15(1).

23. Dalencar BP. Biodança como processo de renovação existencial do idoso. Revista Brasileira de Enfermagem. 2008;61(5):608-614.

24. Catib NOM. Estados emocionais de idosos nas danças circulares. Motriz rev educ fis. 2008;14(1):41-52.

25. Gil PR. Hábitos de lazer e atividade física durante o curso de vida em idosos praticantes de dança. Rev Kairós. 2015;18(2):227-245.

26. Witter C. Envelhecimento e dança: análise da produção científica na Biblioteca Virtual de Saúde. Rev bras geriatr gerontol. 2013;16(1):191-199.

27. Faro AJ. Pequena História da dança. Rio de Janeiro: Zahar; 1986.

28. Fonseca CC. Análise do esquema corporal e imagem corporal na dança de salão e seus aspectos motivacionais. São Paulo: Universidade São Judas Tadeu; 2008.

29. Freire IM. Compasso ou descompasso: O corpo diferente no mundo da Dança. Ponto de Vista. 1999;1.

30. Freitas RD. Danças de salão. Rio de Janeiro: Editora Baltazar; 2008.

31. Hermida JFO. lugar da Educação Física na nova Lei de Diretrizes e Bases da Educação Nacional: trajetória, limites e perspectivas. Revista paranaense de educação física. 2000;1(1):55-65.

32. Houaiss A. Dicionário Houaiss da língua portuguesa. São Paulo: Objetiva; 2001.

33. Papalia DE, Olds SW. Desenvolvimento humano. Porto Alegre: Artmed; 2000.

34. Todaro MÁF, Jacob W. Atividade Física e Envelhecimento Saudável. Rev bras Educ Fís Esp. 2006;20:109-209. 